Postprint of:

Souag, Lameen. 2015. "How to make a comitative preposition agree it-with its external argument: Songhay and the typology of conjunction and agreement". In Paul Widmer, Jürg Fleischer, and Elisabeth Rieken (eds.), Agreement from a diachronic perspective, Berlin: De Gruyter, pp. 75-100. doi: 10.1515/9783110399967-005.

\title{
How to make a comitative preposition agree it-with its external argument: Songhay and the typology of conjunction and agreement
}

\author{
Lameen Souag, LACITO (CNRS)
}

\begin{abstract}
This article describes two hitherto unreported comitative strategies exemplified in Songhay languages of West Africa - external agreement, and bipartite - and demonstrates their wider applicability. The former strategy provides the first clear-cut example of agreement for a previously unattested target-controller pair. Based on comparative evidence, this article proposes a scenario for how these could have developed from the typologically unremarkable comitative and coordinative strategies reconstructible for proto-Songhay, in a process facilitated by contact with Berber. The grammaticalisation chain required to explain this has the unexpected effect of reversing a much better-known one previously claimed to be unidirectional, the development COMITATIVE > NP-AND.
\end{abstract}

\section{Introduction}

In recent years, the domain of conjunction has received increasing attention from typologists, as illustrated by such overviews as Stassen (2003), Lehmann and Shin (2005), Stolz et al. (2006), Haspelmath (2007), Arkhipov (2009), and Palancar (2012). This work provides a fairly comprehensive typology of the domain. Stassen (2003) points out two principal strategies for the encoding of NP conjunction, which he treats as extreme positions on a continuum: coordinative, in which the two NPs involved receive equal structural rank and are both assigned the same theta-role, with extraction possibilities limited by the Coordinate Structure Constraint, and prototypically forcing non-singular agreement; and comitative, in which the two NPs involved receive unequal structural rank and one is treated as oblique, resulting in a structure exempt from the Coordinate Structure Constraint and prototypically allowing singular agreement. The typology of comitative strategies itself has been further elaborated by Lehmann and Shin (2005:43-54): concomitant predication (with a converb/coverb 'be with'); adpositional marking ('with'); case marking ('with'); verb derivation ('with-V', a type of applicative); and incorporation. The commonest of these, according to Stassen, is adpositional or case marking.

Stassen's typology, and in particular the distinction he draws between comitatives and coordinatives, implicitly presupposes that, in structures satisfying the prototypical conditions for the comitative strategy, each noun phrase is expressed only once within the conjunction, allowing unambiguous comparison of their relative ranks. The alternative would involve doubling of at least one noun phrase; to the author's knowledge no example of this phenomenon has been reported in existing surveys of agreement, e.g. Corbett (2006), or of adpositions, e.g. Hagège (2010). However, this article will demonstrate that this alternative is in fact attested: at least three Songhay languages of North and West Africa systematically use comitative strategies - confirmed as such by being exempt from the Coordinate Structure Constraint and taking agreement with only one noun phrase in which the higher-ranked noun phrase is doubled by a pronominal copy (free or bound agreement) 
forming a formally coordinative phrase with the lower-ranked noun phrase.

A priori, while neither Stassen's nor Lehman and Shin's typologies include this possibility, they provide a plausible means for such a development to occur: by a comitative-expressing converb / serial verb retaining agreement. Surprisingly, however, this path turns out not to be a plausible source for the examples of this strategy documented here. Rather, comparative Songhay evidence indicates that these have developed - partly under Berber influence - from an earlier situation, still attested in closely related languages, in which the comitative/coordinative particle was a preposition rather than a verb. This development reverses a better-known grammaticalisation path, COMITATIVE > NP-AND, and contradicts Haspelmath's (2007:29) claim that "Theoretically, one could imagine the reverse diachronic process, from coordinator to comitative, also giving rise to the same synchronic polysemy, but this never happens."

After briefly setting the family-internal context, this article will open with a discussion of the most extreme case of a doubling strategy - a comitative preposition agreeing with its external argument, as found in Kwarandzyey (Songhay, Algeria) ${ }^{1}$. On common assumptions about the emergence of agreement (e.g. van Gelderen 2011), such a phenomenon presupposes a prior stage in which a pronoun doubling the higher rank noun phrase was used, which I term the bipartite comitative; re-analysis of existing data for other Songhay languages demonstrates that this stage is indeed attested there, though only in the more northerly varieties. This makes it possible to propose a tentative outline of the grammaticalisation process involved. The languages in question are independently known to have undergone Berber influence, and comparison to Berber then helps elucidate an otherwise improbable early step in this development. Finally, a few less well documented examples of the same two strategies in languages outside the region are discussed.

\section{The split reflexes of Songhay nda 'with/and' in Kwarandzyey}

In almost all members of the closely knit Songhay family of West Africa (mainly Mali and Niger), a word $n d a$ or $d a$ has the following polysemy:

1) if (complementiser with a phrasal complement);

2) and (conjunction linking noun phrases);

3) with (instrumental preposition);

4) with (comitative preposition).

Such polysemy is cross-linguistically frequent. Identity of instrumentals and comitatives is a relatively widespread pattern, displayed by about a quarter of all languages (Stolz, Stroh \& Urdze 2011), and identity of comitatives and noun phrase conjunctions is found in nearly half of all languages (Stassen 2011). The connection of conditional complementisers to "and", while less well attested, is confirmed by cases like middle English and (early modern an) 'if' < 'and' (Kurath 2001). It thus appears that this polysemy reflects a common etymon, and not coincidental

1 All Kwarandzyey data derives from the author's fieldwork, with grateful thanks to his consultants - in particular Smail and Madani Yahiaoui and Mohamed Ayachi - and to the Arts and Humanities Research Council. Thanks are also due to the British Academy and the Centre National de la Recherche Scientifique for funding post-doctoral research, to Catherine Taine-Cheikh for Zenaga examples, and to anonymous reviewers for comments. On the grammar of Kwarandzyey, see Souag (2010a) and the references given there, notably Cancel (1908); for sound shifts, see Souag (2010b) The transcription used here is based on the former; however, the second element of affricates is transcribed superscript, and elided vowels are written with an overstrike line (e.g. $\theta$ ) rather than being omitted from the transcription. Abbreviations in glosses added by the author follow the Leipzig Glossing Rules, with the addition of Emph 'emphatic (pronoun)', ABS.GEN 'absolute genitive', INC 'inceptive', AntiAgr 'antiagreement'. 
convergence from multiple sources.

Kwarandzyey, spoken at the oasis of Tabelbala in Algeria a thousand kilometres from the nearest Songhay-speaking town, has undergone intense Berber and Arabic influence and prolonged isolation from other Songhay varieties, resulting in numerous divergences from mainstream Songhay through both innovation and retention. In Kwarandzyey, three of the functions of panSonghay $n d a$ are reflected by $n d^{z} a$ (the shift of $d>d^{z}$ is regular before non-emphatic vowels):

(1)
'if':
$n d^{z} a$
if
$l \hbar s ̌ i s ̌ ~ b a ̣$
$\boldsymbol{t}-k a$
plant exist $3 \mathrm{Sg}-\mathrm{LOC}$
$n \partial-m-d^{2} u \gamma^{-} a$ 2S-IRR-uproot-3Sg

'If there are weeds in it, you uproot them.'

(2) 'NP-and':

$\begin{array}{lcl}y u=y u \quad n d^{z} a & f \partial \dot{r} k a=y u \\ \text { camel=Pl and } & \text { donkey=Pl } \\ \text { 'camels and donkeys' } & \end{array}$

(3) 'with (instrumental)':

$n \partial-m-y a d a \quad a-k a \quad n d^{z} a \quad n \partial-n \quad t^{s} i$

2Sg-IRR-step 3Sg-LOC INS 2Sg-GEN foot

'you step on it with your foot'

In certain contexts, $n d^{z} a$ has also acquired various spatial usages ('from', '(passing) by'), not relevant here.

However, in contrast to other Songhay languages, 'with (comitative)' is expressed not by $n d^{z} a$, but by the preposition $i n d^{z} a$ preceded by an agreement marker:
Sa-m-ka
Sa-m-gwa
Sa-ind ${ }^{z}$-ana
$1 \mathrm{Sg}$-IRR-come
1Sg-IRR-sit 1Sg-COM-3SgEmph

'I will come and sit with him.'

In order to understand this unexpected development, it is necessary first to examine the synchronic facts more closely.

\section{The morphology and syntax of ind $\mathrm{d}^{\mathrm{a}}$}

\subsection{The controller of the agreement prefix}

As the previous example illustrates, the agreement marker prefix of $i n d^{z} a$ does not agree with the object of the preposition; rather, it expresses the other participant in the comitative relation. A comitative relation involves two parties: the accompanied, and the accompanier. In "I went with him", "I" is the accompanied party, and "him" the accompanier; in "I left you with them", "you" is the accompanied party, and "them" the accompanier. In English, the accompanied is left unstated within the prepositional phrase, and is deduced from the rest of the sentence. But in Kwarandzyey, the agreement prefix on $i n d^{z} a$ agrees in number and person with the accompanier. Typically, this coincides with the subject of the clause, e.g.: 
(5)

$x^{w} \partial d$

gga

na-b-yaxdam

$n$-ind ${ }^{z} a$

$n \partial-n$

$b a=y u \ldots$

when

PST

2Sg-IPFV-work 2Sg-COM

2S-GEN

friend $=\mathrm{Pl}$

'When you (sg.) were working with your friends...'

(6)
ant $=a$
$g g^{w} \operatorname{rrg}^{w}$ วy $\emptyset$-ind $\boldsymbol{a}^{z}$
yuna
3SgEmph=FOC
fight
3-COM
that

'It's him that fought with that person.'

(7)
$i \check{s} k a d d a=\gamma u, \quad k s$
$y$-aSam- $d^{z} y \partial y$
$y-$ ind $^{z}-a$
child=this, let
1Pl-FUT-talk
1PI-COM-3SG

'This little kid, let's talk with him.'

(8)

\begin{tabular}{|c|c|}
\hline $\begin{array}{l}g g a \\
\text { PST }\end{array}$ & $t^{s} u \gamma$ \\
\hline
\end{tabular}

'What did you (pl.) used to do with' ${ }^{2}$ them [=locusts, a collective singular in

Kwarandzyey]?'

(9) $\quad i-m-k a \quad \emptyset$-ind $\boldsymbol{d}^{2}-\boldsymbol{a}$

3Pl-IRR-come 3-COM-3Sg

'They'll come with him.'

However, examples can be found where it coincides with the morphological object rather than the subject:
Sa-kkas-ni
$n-$ ind $^{z}-a$
1Sg-leave-2Sg
2Sg-COM-3Sg
'I left you with him.'

or even with the indirect object:
tsuyt $=a$
yașra
$n i-\check{s} \dot{i}$
n-indz-ana
what=FOC happen you-DAT 2Sg-COM-3SgEmph
'What happened to you with him/it?'

\subsection{The paradigm of $i n d^{z} a$}

The full paradigm of $i n d^{z} a$, illustrated in the examples above, is given in Table 1:

\section{Table 1. Paradigm of ind ${ }^{\mathrm{z}} \mathrm{a}$.}

$$
\begin{aligned}
& \text { S(a)-ind }{ }^{z} a \text { "1Sg-with" } \quad y(a) \text {-ind } a \text { "1Pl-with" } \\
& n \text {-ind } d^{z} \text { "2Sg-with" } \quad n d z \text {-ind } d^{z} a \text { "2Pl-with" } \\
& \emptyset \text {-ind } a^{\prime} \text { "3Sg/Pl-with" }
\end{aligned}
$$

These prefixes are quite distinct from the free pronouns listed in Table 2 (although their common origin is still evident):

2 Despite the ambiguity of the English translation, this is comitative, not instrumental; it was answered with "When locusts came, we would make smoke against them", i.e. what they would do when locusts were present with them, not what they would do using locusts. 
Table 2. Kwarandzyey free pronouns.

$\begin{array}{ll}\text { ayəy "1Sg" } & \text { yayu " } 1 \mathrm{Pl} " \\ n i \text { "2Sg" } & n d^{z} y u \text { "2Pl" } \\ \text { ana "3Sg" } & \text { ini "3Pl" }\end{array}$

They bear a far closer similarity to the subject agreement prefixes used with verbs (Table 3), differing from the latter only in not distinguishing 3rd singular from 3rd plural:

Table 3. Kwarandzyey subject agreement.

$\begin{array}{ll}\mathcal{S}(a)-" 1 \mathrm{Sg} " & y a-" 1 \mathrm{Pl} " \\ n \partial-" 2 \mathrm{Sg} " & n d{ }^{2} \text { " } 2 \mathrm{Pl} " \\ \emptyset-/ a-" 3 \mathrm{Sg} " & i-" 3 \mathrm{Pl} "\end{array}$

\subsection{Establishing ind ${ }^{z} a^{\prime}$ s word class}

Both the use of subject prefixes and their form suggest that $i n d^{z} a$ might be a verb. However, other tests rule this out. In Kwarandzyey, any verb can act as a predicate without any copula or existential verb, and can take mood and negation markers. ind ${ }^{z} a$ cannot stand alone as a predicate; to form a predicate expressing a comitative relation, $b a$ "exist" must be used:

$$
\begin{aligned}
& \text { *(n-ba) n-ind }{ }^{2} a-\text {-yəy } \\
& \text { *(2Sg-exist) 2Sg-COM-1Sg } \\
& \text { 'You *(are })^{3} \text { with me.' }
\end{aligned}
$$

Nor can $i n d^{z} a$ take mood/aspect/negation markers:

$$
\begin{aligned}
& \text { *nə-s-indza-yəy } \\
& \text { *2Sg-NEG-COM-1Sg } \\
& \text { (ungrammatical for any reading) } \\
& \text { *nə-mm-ind } a \text {-yəy } \\
& \text { *2Sg-IRR-COM-1Sg } \\
& \text { (ungrammatical for any reading) }
\end{aligned}
$$

Instead, comitative relations are negated as follows:

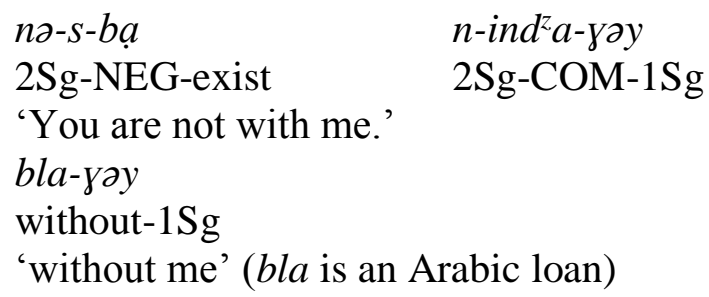

and irrealis mood is expressed on the Arabic loan verb ikun 'exist, always be' ( $b a$ 'exist' is defective, taking negation markers but not mood/aspect ones):

$$
\begin{array}{ll}
\text { nə-mm-ikun } & n-i n d^{z} a-y \partial y \\
\text { 2Sg-IRR-exist } & \text { 2Sg-COM-1Sg } \\
\text { 'You will be with me.' } &
\end{array}
$$

3 Throughout this paper, in accordance with common practice, the notation $*(X)$ means that the omission of $\mathrm{X}$ results in ungrammaticality, whereas $(* \mathrm{X})$ would mean that the insertion of $\mathrm{X}$ results in ungrammaticality. 
Ind $d^{z} a$ cannot be classed as a noun either. Nominal complements always take a genitive case marking postposition $n$ and precede the noun. Nominal adjuncts of nouns follow the noun, but take a postposition wani/wini. Thus:

$$
\begin{aligned}
& d w a \quad \text { gung=wani } \\
& \text { medicine stomach=ABS.GEN } \\
& \text { 'stomach medicine' }
\end{aligned}
$$

$\begin{array}{lll}t^{s} \text { arfas } & *(n) & d^{z} \partial y^{w}=y u \\ \text { truffle GEN } & \text { uproot=Pl } \\ \text { 'truffle-digging' } & \\ & \\ \text { xalad } \quad *(n) & \text { yimma } \\ \text { Khaled } \quad \text { GEN } & \text { mother } \\ \text { 'Khaled's mother' } & \end{array}$

The most striking confirmation of its non-verbal, non-nominal status is afforded by relativisation and WH-question formation. In relativisation and WH-questions, verbs unsurprisingly remain in situ when their objects are extracted - in other words, verbs are never pied-piped - as illustrated by the following examples (in which the expected position for the relevant argument in a declarative main clause is marked with $t$ ):

$$
\begin{array}{llll}
a r=d^{2} \dot{t} & \text { Sa-ggwa } \quad \mathrm{t} & \text { binuw } \\
\text { man=REL } & 1 \text { Sg-see } t & \text { yesterday } \\
\text { 'the man I saw yesterday' } &
\end{array}
$$

$$
\begin{array}{ll}
t \text { siruw }=d^{z}=i \quad a-g g^{w} a-b-s k u-n d z a & \mathrm{t} \\
\text { bird=REL=Pl 3Sg-INC-IPFV-be caught-CAUS } & t \\
\text { 'the birds he kept catching' } &
\end{array}
$$

$t^{s}$ uyt $\quad$ nə-nya t?
what? 2Sg-eat $t$
'What did you eat?'

Nor, for that matter, are genitive nouns pied-piped in relativisation - they remain in situ, using either a resumptive pronoun or a dative strategy:

$$
\begin{array}{lccc}
\text { laqfar }=d^{z} \dot{i}=s i & n \partial-b b a d d a l & \text { an } & k a p k a b u \\
\text { lock=REL=DAT } & \text { 2Sg-change } & \text { 3Sg.GEN } & \text { key } \\
\text { 'the lock whose key you changed' (lit. 'the lock to whom you changed its key') }
\end{array}
$$

Adpositions, by contrast, are regularly pied-piped. Pied-piping is obligatory for the case-marking postpositions si and $k a$, and optional for the instrumental preposition $n d^{z} a$ :

$$
\begin{aligned}
& \text { ljamə } \mathcal{E}=\left[d^{z} \boldsymbol{i}=k a\right] \quad \text { yə-ggənga } \\
& \text { mosque }=[\text { REL }=\text { Loc }] \quad 1 \mathrm{Pl} \text {-pray } \\
& \text { 'the mosque in which we prayed' }
\end{aligned}
$$


$\left[t^{s} u y^{t}=s \dot{t}\right]=a \quad n \partial-d d^{z} i w-a ?$

[whom?=Dat]=Foc 2Sg-send-3Sg?

'To whom did you send it?'

$\begin{array}{lccll}\text { stilu } & {\left[n d^{z} \boldsymbol{t}\right.} & \text { uyudz } \dot{\boldsymbol{t}}] & \text { ogga } & \text { Sa-b-iktəb } \\ \text { pen } & {[\mathrm{INS}} & \text { REL] } & \text { PST } & 1 \mathrm{Sg} \text {-IPFV-write } \\ \text { 'the pen [with which] I was writing' } & & \end{array}$
$\left[n d^{z} a\right.$$$
\left.t^{s} u \gamma_{t}\right]
$$
$n-b a b-k a ?$
[INS
what?]
2Sg-PROG-hit?

'With what (=which hand) do you normally hit?'

although $n d^{z} a$ is also allowed to appear in situ with a resumptive pronoun:
$a-b-q \partial t t$
$n d^{z}-a$
litt ${ }^{\mathrm{s} i n}$
knife=REL PST 3Sg-IPFV-cut with-3Sg
oranges
'the knife that you were cutting oranges with'

Just like $n d^{z} a$, ind $d^{z} a$ may be pied-piped or left in situ with a resumptive pronoun, and shows normal agreement marking in either case:

Pied-piped:
(30) San
$b a=y u \quad\left[\mathcal{G}-\right.$ ind $^{2} \boldsymbol{t}$
uуud'ì agga Sa-b-yəxdəm
my friend=Pl [1Sg-COM
Rel] PST 1Sg-IPFV-work
'my friends with whom I was working'

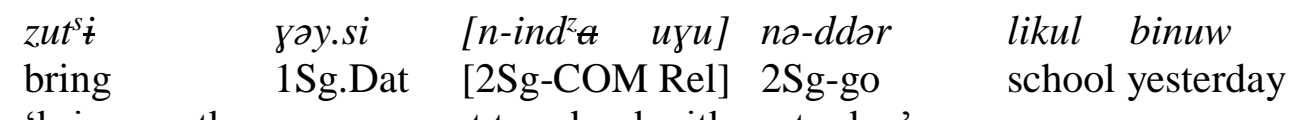

'bring me the one you went to school with yesterday'
[n-indza $\quad$ tsuyt $]=a$
no-dri?
[2Sg-COM what?]=Foc
2Sg-go?
'Who did you go with?'

In situ:
Sa-nn-a
$a r=d^{z} \dot{t}=s i$
agga $\quad$-ba
S-ind $d^{2}-a$
binuw
$1 \mathrm{Sg}$-give-3Sg man=REL=DAT PST $1 \mathrm{Sg}$-exist
'I gave it to the man I was with yesterday.'
$1 \mathrm{Sg}$-with-3Sg yesterday

The former possibility also rules out an analysis of $i n d^{z} a$ as a conjunction under most assumptions, since extraction of the right conjunct would violate the Coordinate Structure Constraint (Ross 1986).

Therefore, indza is best regarded as a preposition.

\subsection{AGR+ind ${ }^{z} a^{\prime}$ s other function: in conjunction}

The conjunction $n d^{z} a$ 'and' is distinct from $i n d^{z} a$ not just functionally but also phonetically (by the lack of initial $i$-), morphologically (by the lack of an obligatory agreement prefix), and syntactically (not being used to mark adjuncts of the verb phrase). Examples of its usage include: 
[ayyub $\quad n d^{z} a \quad$ lmahdit] i-ggworgway ya-si.

[Ayoub and Mahdi] 3Pl-fight 1Pl-Dat

'[Ayoub and Mahdi] fought on us (i.e. fought, inconveniencing us.)'

$\begin{array}{lllll}\text { Sa-gga } & {[\text { San }} & \text { obba } & n d^{z} a & \text { Sa-yəmma] } \\ \text { 1Sg-find } & {[\mathrm{my}} & \text { father } & \text { and } & 1 \mathrm{Sg} \text {-mother]. }\end{array}$

'I found [my father and my mother].'

However, when (and only when) the first conjunct happens to be a pronoun, the expected form $n d^{z} a$ gets replaced by AGR+ind $a$. Contrast the following cases, elicited in pairs to maximise parallelism:

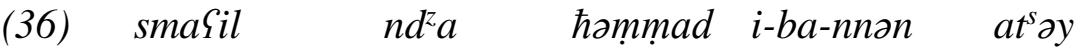

Smail and Hammad 3P-PRF-drink tea

'Smail and Hammad have drunk tea.'

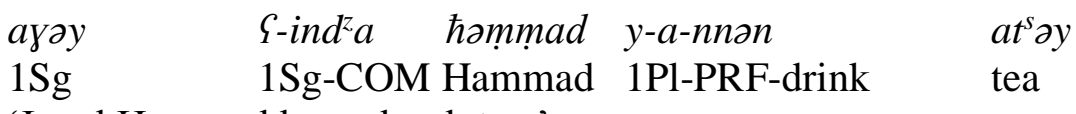

'I and Hammad have drunk tea.'

\begin{tabular}{|c|c|}
\hline $\begin{array}{l}\text { way } \\
\text { neet }\end{array}$ & $\begin{array}{l}\text { smaSil } \\
\text { Smail }\end{array}$ \\
\hline
\end{tabular}

'He met Smail and Hammad.'

(39) $\quad a-k^{w} b^{w}$ yy $\quad n$-ind $a \quad \hbar \partial m m m a d$

3Sg-meet 2Sg-COM Hammad

'He met you and Hammad.'

In such instances, the subject agreement marker matches in number and person the combination of the two conjuncts, e.g. "I and Hammad" (=we), rather than matching either of the two conjuncts, confirming that we are dealing with conjunction and not with a comitative adjunct. Thus:

(40) Sabdolqadər $n d^{z} a \quad x a l a d \quad i-k k u$

Abdelkader and Khaled 3Pl-tall

'Abdelkader and Khaled are tall.'
$n-$ ind $^{2}-a$
$n d^{z} \partial-k k u$
2Sg-COM-3Sg
2Pl-tall
'You and he are tall.'

\section{Comparative background}

\subsection{Family-internal reconstruction}

Songhay is a fairly close-knit family with no proven relatives, much less any relatives close enough to be relevant to reconstruction. It has two principal branches: Eastern Songhay (with relatively few shared innovations) to which most Songhay speakers and languages belong, and 
Northwestern Songhay (with many clear shared innovations), itself sharply divided into two distinct subgroups, Northern Songhay (to which Kwarandzyey belongs) and Western Songhay (Souag 2012). While much descriptive work remains to be done on Songhay, there are already at least three Songhay languages for which sufficiently detailed grammars now exist to allow comparison, and more limited data is available for a wider range. From South to North, these are Tondi Songway Kiini (TSK) around Kikara in southern Mali (Heath 2005), Koyraboro Senni (KS) around Gao in eastern Mali (Heath 1999a) - both Eastern - and Koyra Chiini (KC) around Timbuktu in northeastern Mali (Heath 1999b), in the Western branch. The dialect of Timbuktu may be expected to be particularly relevant to comparison with Kwarandzyey, as the oasis of Tabelbala was historically a stop on the trade route between southern Morocco and Timbuktu. In the following examples, note that serial verbs in all non-Northern varieties are formed with reflexes of the preverbal non-finite particle *ká (in TSK also $d i$ ), unattested in combination with the comitative; this rules out a serial verb interpretation of the comitative anywhere in Songhay.

In Kikara, the comitative is a plain preposition showing no agreement marking, homophonous with "and" and with the instrumental; Heath states that "The postverbal sequence dá X... can be instrumental... or comitative..." (2005:139), e.g.:

$\begin{array}{lrll}\text { ày } & \text { góy } & \text { dá } & n \hat{\imath}: \\ \text { 1Sg } & \text { work } & \text { with } & 2 \mathrm{Sg} \\ \text { 'I worked with you.' } & & \\ \text { (Heath 2005:139) } & & \end{array}$

In relativisation, it is treated like a postposition, e.g. :
hòró á
$\breve{a} y$
kèré
ká dá áy
már
$\begin{array}{lll}k a ́ & k o ́ y & m o ́ t i \\ \text { Infin } & \text { go } & \text { Mopti }\end{array}$
Dem it-is $1 \mathrm{Sg}$-Poss friend Rel with $1 \mathrm{Sg} \mathrm{Impf}^{4}$ join Infin go Mopti
'This is my friend, with whom I will go to Mopti.'
(Heath 2005:198)

This plain preposition strategy is well attested in other, less fully described Songhay varieties, from both principal Songhay subgroups. It is found in Zarma (Eastern Songhay, Niger):

$\begin{array}{lllll}\text { dà } & \text { ifòo } & n & \hat{a} & \text { koy } \\ \text { with } & \text { who } & \text { FOC } & 3 \mathrm{Sg} & \text { go }\end{array}$

'Avec qui est-elle partie?'

'Who has she left with?'

(Sibomana 2008:105)

\begin{tabular}{|c|c|c|c|c|c|c|}
\hline ay & $g a$ & koy & fari & $n d a$ & ay & $i z-e y$ \\
\hline I & IPFV & go & field & with & I & child-Def.Pl \\
\hline
\end{tabular}

and in Hombori (Eastern Songhay, Mali):

$4 \quad$ <'> represents a morpheme with no segmental realisation but affecting the tone of the subsequent syllable. 
(46)

ái sù bá $\quad$ w góy ńd-à

1SgS ImpfNeg want Inf work with-3Sg

'I don't want (or like) to work with him/her.'

(Heath 2007:sec. 5.11.3)

and even in the heavily Berberised Northern Songhay language, Tadaksahak:

$\begin{array}{llll}a-b \text {-háng }(a) & \text { ond }(a) & a ́ y=n & \text { caráy } \\ \text { 3S-IMPERF-accompany } & \text { with } & 3 \mathrm{~S}=\mathrm{GEN} & \text { friend }\end{array}$

'He accompanies his friend.'

(Christiansen-Bolli 2010:121)

It therefore appears reconstructible for proto-Songhay.

Timbuktu and Gao each share four strategies for expressing comitative relations. Three of these have no clear Kwarandzyey counterpart: a postposition banda (Timbuktu) / bande (Gao) "after/behind" (paralleled in Zarma, cf. Sibomana (2008:74)), a derivational verbal suffix - nda which Heath derives from the homophonous preposition (arguably paralleled in Zarma by Sibomana's (2008:75) "directive"), and (rarely, according to Heath) a preposition nda (with parallels throughout the family, as seen above). The remaining strategy, however - described by Heath for Timbuktu (1999b:117) as: "a conjunction including the other associated referent, even if repeated: 'I went there [I and him]', meaning 'I went there with him."'- is remarkably similar to Kwarandzyey:

$\begin{array}{llllll}\text { ay } & \text { čindi ha } & \text { goro agey } & \text { nda } & P \\ 1 \mathrm{SgS} & \text { remain Inf sit } & 1 \mathrm{Sg} & \text { and } & \mathrm{P} & \end{array}$

'I was sitting with P.' (Gao)

(Heath 1999a:152)

We may label this the "bipartite comitative".

Heath's description of relativisation out of comitatives in Timbuktu and Gao is based on the preposition $n d a$ strategy; he indicates that "Instr-Comit $n d a$ does not move and remains stranded in postverbal position" (1999b:167), e.g.:

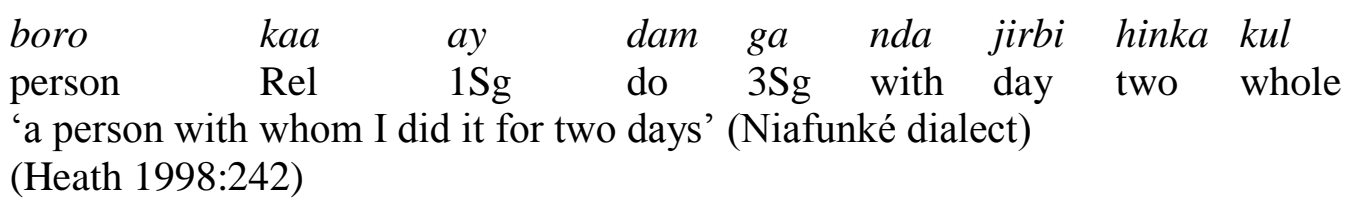

He also describes both Timbuktu and Gao as allowing relativisation out of conjuncts, which he treats separately. Since this violates the Coordinate Structure Constraint (at least where a gap strategy is used, as in the second example below), this would strongly suggest that the "conjuncts" in question be reinterpreted as bipartite comitatives; and indeed, many of his examples of this appear equally easy or easier to understand as such, e.g.:

$\begin{array}{lllllllll}\text { ay na } \quad \text { duu } & \text { bor } & \text { kaa } & \text { ay } & \text { nda } & \text { ga } & o & \text { nin } & \text { hari-futu } \\ \text { 1SgS Neg get } & \text { person } & \text { Rel } & \text { 1SgS } & \text { and } & \text { 3SgO } & \text { Impf } & \text { drink } & \text { water-bad } \\ \text { 'I haven't found anyone to drink beer with.' } & & & & \end{array}$


hay di kaa yerkoy kuboy-ndi ey nda $\varnothing \quad$ či $\quad$ woo yo

thing Def Rel God meet-Caus 1SgO with $(t)$ be Dem Pl

'The thing that God caused me to meet with was these people.'

(Heath 1999b:137)

$\begin{array}{llll}\text { bor-ey kay } & \text { agey } & \text { nd-ey } & \text { yenje } \\ \text { person-DefPl Rel } & \mathbf{1 S g} & \text { and-3PIO } & \text { fight } \\ \text { 'the people who I and they fought' } & & \\ \text { (Heath 1999a:247) } & & \end{array}$

A natural interpretation of the data is that the bipartite comitative strategy is used in relative clauses too, though apparently only with $n d a$ in situ.

Given the distribution so far, we may expect to find similar examples in less well documented northerly Songhay languages, and this appears to be borne out by a few examples attested in the very inadequately documented Northern Songhay language of In-Gall (Niger), Tasawaq:

$\begin{array}{ll}\text { iru-hunu iri-nda iri-n-amgari fo } \\ \text { 1Pl-go out 1Pl-with 1Pl-GEN-chief } & \text { one } \\ \text { 'On est sorti avec notre chef.' } & \\ \text { 'We went out with one of our chiefs.' } \\ \text { (Rueck \& Christiansen 1999:28) }\end{array}$

No data is available for this language that would bear upon the extraction tests, however.

Putting all this together yields a prima facie plausible account for how the Kwarandzyey situation emerged:

1. In Proto-Songhay, *ndá had at least the three functions of marking the comitative, marking the instrumental, and forming noun phrase conjunctions, as it still does in Kikara.

2. Fairly early on, in northerly dialects, there emerged an initially stylistic option of expressing a comitative with a conjunct referring back to the subject : "I went there, I and X" = "I went there with X." Since Songhay has strict Subject-Verb order, the only immediately obvious source for this would be an afterthought construction "correcting" the subject, but in fact, a look at the contact situation suggests an alternative source for this step, as shown below.

3. This bipartite means of expressing the comitative became systematic and common in northerly Songhay varieties like Timbuktu and Gao.

4. In Kwarandzyey, other comitative strategies were lost (or never developed), leaving this method as the only one; it was thus generalised to cases, such as "I left you with him" or "I am with him", where the original literal meaning would have been inappropriate.

5. In Kwarandzyey, pronouns in subject-like positions (as subjects before verbs, or before genitive markers) - in specifier positions, to use X-bar theory terminology - got fused to the following element, and phonetically modified with irregularities like ayzy $>\mathcal{G}$-, and no plural marker $y u$ in $y a-, n d^{z}$-, as seen in Table 4. Non-third-person initial pronouns (at least) 
in the comitative construction got treated the same way as weak subject pronouns, following the well-known Agreement Cycle (noun/oblique/emphatic > first/second person pronoun > clitic > agreement; cf. van Gelderen (2011:18) for a recent version.)

Table 4: Kwarandzyey pronominal system

\begin{tabular}{|c|c|c|c|c|}
\hline & Standalone & $\begin{array}{l}\text { Prefix } \\
\text { (verbs/ind } z a / \text { genitives) }\end{array}$ & $\begin{array}{l}\text { Object } \\
\text { (of verb/preposition) }\end{array}$ & $\begin{array}{l}\text { Object } \\
(\text { of } s i / k a)\end{array}$ \\
\hline $1 \mathrm{Sg}$ & ауду & $S(a)-$ & -уәу & уәу- \\
\hline $2 \mathrm{Sg}$ & $n i$ & $n-$ & $-n i$ & $n i-$ \\
\hline $3 \mathrm{Sg}$ & ana & $a-/(\varnothing)$ & $-a /$ ana & $a-$ \\
\hline 1Pl & уауи & $y a-$ & $-y а у и$ & $y a-$ \\
\hline $2 \mathrm{Pl}$ & $n d^{z} y u$ & $n d^{z_{-}}$ & $-n d^{z} y u$ & $n d^{z} i-$ \\
\hline $3 \mathrm{Pl}$ & $i n i$ & $i-$ & $-i / i n i$ & $i-$ \\
\hline
\end{tabular}

\subsection{Language-internal reconstruction}

The scenario outlined above leaves one important problem unaccounted for: the $i$ - in $i n d^{z} a$. An examination of Kwarandzyey's historical development suggests an explanation (although contact may also have played a role, as seen below).

Kwarandzyey has undergone a wholesale reshaping of its vowel system, in which almost all short vowels in closed syllables, short low toned vowels, and final $-i / u$, were reduced to schwa or zero. However, the reduction of final vowels in the verbal subject agreement markers may have preceded all these changes. Not only is it common for grammaticalisation to lead to phonetic simplification, but - as Table 5 shows - similar reduction has taken place in the subject agreement prefix system of the closely related language Tadaksahak (Christiansen-Bolli 2010:114), where these vowel changes have not affected the rest of the vocabulary:

Table 5: Tadaksahak pronominal system (in part)

$\begin{array}{lll}1 \mathrm{Sg} & \text { ayáy } & \text { ay }(a)- \\ 2 \mathrm{Sg} & \text { nín } & n i-/ \partial n- \\ 3 \mathrm{Sg} & \text { áyga } & a- \\ 1 \mathrm{Pl} & \text { áari } & \text { ar(ə)- } \\ 2 \mathrm{Pl} & \text { ándi } & \text { and(ว)- } \\ 3 \mathrm{Pl} & \text { íngi } & i-\end{array}$

In what we may reconstruct as the pre-Kwarandzyey comitative paradigm, $i / y$ would have preceded $n d a$ in four of the six slots, as seen in Table 6 :

Table 6: Pre-Kwarandzyey comitative paradigm (reconstructed)

*ayay nda *yer nda

*ni nda *indi nda

*a nda *i nda

This fact alone would have encouraged metanalysis of the $i$ in these forms as part of the stem, despite the maintenance of $n d a$ in other contexts. If, as the Tadaksahak data suggests, the reduction of the prefixes preceded the merger of short vowels to schwa in closed syllables, then the motivation for reanalysis would be even stronger. Since the verbal subject agreement markers had 
already lost this vowel, these could readily be reinterpreted as $*_{i n d-i n d a,} *_{n}$-inda, etc., bringing the paradigm closer to the verbal subject paradigm. The paradigm was then re-regularised on the new base. The preservation of the vowel is regular for vowel-initial words even in closed syllables, as illustrated in Table 7:

Table 7: Some vowel-initial cognates

$\begin{array}{lll} & \text { Kwarandzyey Kaado (Ducroz \& Charles 1978) } \\ \text { two inka } & \text { hínká } \\ \text { three inza } & \text { hínzà } \\ \text { boy izi } & \text { izè }\end{array}$

So instead of being swept away by sound change, the $i$ in this paradigm got reinterpreted as part of the stem: $n i-n d a>n-i n d^{z} a$. This further disambiguated the comitative from the instrumental.

Throughout the whole process, the original function of these forms - to express conjunctions whose first element was a pronoun - was also retained; despite appearing anomalous synchronically, the common form reflects a common origin.

\subsection{Bipartite comitatives in Berber and their influence}

Gao, Timbuktu, and Kwarandzyey and Tasawaq are not expected to share innovations for genetic reasons; as seen above, they belong to three different branches of Songhay. However, they do share a common contact history: all four, but especially Kwarandzyey and Tasawaq, have undergone heavier influence from Berber than their more southerly relatives, as a result of their location in, or at the southern edge of, the Sahara, and of their role in the trans-Saharan trade. For the past four centuries or so, the relevant varieties have been Southern Atlas Tamazight (shading into Tashelhiyt) for Kwarandzyey, and Tuareg for the others; previously, all of them were also in contact with Șanhāja tribes speaking Western Berber languages related to Zenaga and Tetserrét, whose influence is conspicuous in Kwarandzyey (Souag 2010a; Souag 2010b). On this basis one might therefore suspect some role for contact in this development, and examination of Berber supports this hypothesis.

Bipartite comitatives have attracted relatively little descriptive attention in Berber, as elsewhere; however, comitative constructions at stages $2 / 3$ of the cycle proposed above turn out to be quite common in the family. Data relevant to the syntactic tests that confirm their existence within Songhay can be found in already published materials for the principal varieties which have influenced Songhay. For Tashelhiyt (Morocco), we find frequent textual examples in which the verb agrees with only the first element of a pronoun + noun phrase pair linked by $d$ 'and', where the latter may precede predicate-internal adjuncts and afterthoughts, as in the following case:

$$
\begin{aligned}
& i \text {-bQa=d nTa d-tmgart } \dot{g} \operatorname{tgMi} \mathrm{Li} \text { sin } i T \text {-sn d-twaYa } \\
& \text { 3MSg-remain.IMPF=hither he and-woman in house ANA two with-3MPl and-slave } \\
& \text { 'Il vivait dans la maison avec la femme et l'esclave.' } \\
& \text { 'He stayed in that house with the woman, both of them with the slave.' } \\
& \text { (Boukous 1977:202) }
\end{aligned}
$$

The translations of such phrases provided by native speakers are consistently comitative, not coordinate. More tellingly, the second element of such a form can be a question word, which by the Coordinate Structure Constraint forces a comitative interpretation of the construction: 
nTan $d \quad$ mit a i-Da-n?

he and who? FOC AntiAgr-go-AntiAgr

'Avec qui est-il parti?'

'Who did he leave with?'

(Destaing 1914:28)

For Tamazight (southeastern Morocco), textual examples seem less frequent but are again available (Ait Atta variety):
yak ur te-nnay-t
kiyyi $d \quad k a$ ?
surely not $2 \mathrm{Sg}$-dispute- $2 \mathrm{Sg}$
'Tu t'es disputé avec quelqu'un?'
you and some
'You haven't argued with someone, have you?'
(Amaniss 1980:735)

They include cases where the internal argument is questioned:
$y$-iri
a $\quad y$-isin
nettat $d \quad m i$
3MSg-want IRR 3MSg-know she and who
'[Il] voulut savoir avec qui.'
'He wanted to know who [she had done it] with.'
(Amaniss 1980:737)

The other Berber language spoken near Tabelbala, Taznatit (southwestern Algeria), shows the same construction:
te-ššu nettat $d \quad$ ugid ns
3FSg-eat she and man 3SgGen
'Elle mangea avec son mari.'
'She ate with her husband.'
(Bellil 2006:159)

As for Zenaga, a prima facie example of a bipartite comitative can be found in the barely 31 pages of texts published in it:
gahūh ad' ̌̆a-nša
onto id' tặ̆ăbalt-ạs
id' tamarūss-əs
hyena IRR 3MSg-spend_night he and mother_in_law-3SgGen and bride-3SgGen
'(Ils disent que) l'hyène a passé la nuit elle avec sa belle-mère et sa femme'
or $\quad$ addo
at some.people
'chez quelques gens. (footnote: dans un campement quelconque).'
'(They say that) the hyena spent the night with his mother-in-law and his wife at some people's camp.'
(Nicolas 1953:89)

The as yet unpublished corpus gathered by Catherine Taine-Cheikh (p.c.) provides further examples of bipartite comitatives, all subject-oriented, such as: 


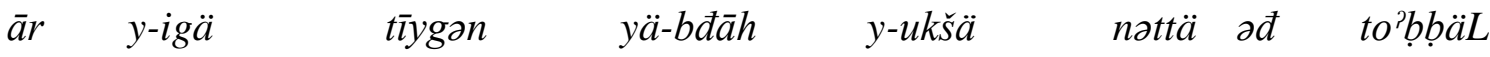

when 3MSg-become tomorrow 3MSg-go 3MSg-herd he and slave.F

'Quand vint le lendemain il partit faire paitre lui et la servante.'

'When the next day came, he went to herd with the slave.'

Bipartite comitatives are also common in Berber languages with no known contact with Songhay. One clear example is Algeria's second largest Berber language, Chaoui (eastern Algeria). Penchoen (1973) explicitly discusses the problem of post-verbal coordinate subjects agreeing with the first conjunct, and provides an example where this construction is directly coordinated with a prepositional comitative:
ruh w.h.h.d-k
$n \cdot 8$
$\check{s} . k k d-u m a-k$
ny id.n-mmi-s
go alone-2Sg or you and-brother-2Sg or with-son-3Sg
'Va seul ou ensemble avec ton frère ou avec ton cousin!'
'Go alone or with your brother or with your cousin!'
(Penchoen 1973:190)

S-S.mmi-k

of-uncle-2Sg

In all of the previous cases, the connector is identical to the usual NP conjunction "and". However, in Zuaran (northwestern Libya), Mitchell (2009:87) highlights a context, which he terms "conjoint pronouns", where the connector is synchronically distinct from both NP-and and the nonagreeing comitative preposition: forms such as nšidos 'I and him/her', analysable as $n \check{s}$ - < notš, the free pronoun 'I', a linking element -id etymologically connected to did 'with' and $d$ 'and' but synchronically distinct, and $-s$ '3sg.'. Where these occupy postverbal subject position, verbal subject agreement is with the first conjunct. Several examples are given, e.g.:

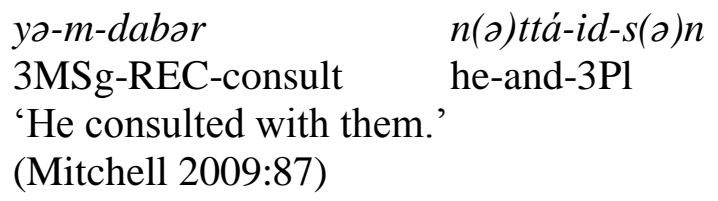

The $i$ - in $i d$-, contrasting both with $d$ "and" and with $d i d$ - "with", parallels the irregular addition of $i$ - found in Kwarandzyey.

Bipartite comitatives are thus fairly common, and geographically rather widespread, in Berber, although their precise syntax calls for more detailed fieldwork. Songhay influence in most of the Berber languages above is not supported by independent evidence, and appears quite improbable. By contrast, Berber influence on Songhay is prominent, particularly in the northerly varieties which display bipartite comitatives, as seen above. Since in Songhay the bipartite comitative is so far attested only in those areas where Berber influence is most prominent, and since Zenaga belongs to the branch of Berber which first influenced Songhay, this first stage of the development in Songhay is best interpreted as a calque of Berber. The Berber forms sometimes exhibit an initial $i$-, which may have influenced the irregular development $n d^{z} a>i n d^{z} a$ within Kwarandzyey.

Berber, unlike proto-Songhay, has subject agreement (with pro-drop) and unmarked VerbSubject order for non-topical subjects; like proto-Songhay, it seems to have originally expressed "and" and "with" identically, as $d$. Thus within Berber, the transition from 1. to 2. can be envisioned as a simple reinterpretation of a postverbal subject pronoun, when followed by a comitative, as forming part of the comitative: 
$\mathrm{V}+\operatorname{AgrS}$ Pron $_{\mathrm{S}}\left[\right.$ with NP] $>\mathrm{V}+\operatorname{AgrS}(\mathrm{S})\left[\mathrm{Pron}_{=\mathrm{S}}\right.$ with NP]

'went he [and/with his brother]' > 'went (the man) [he and/with his brother]'

Postulating that Songhay simply calqued the reanalysed structure from Berber makes it unnecessary to suppose that afterthought forms were reanalysed as a core constituent of the sentence.

\section{Bipartite and external agreement comitatives beyond Songhay}

Neither of the comitative strategies mentioned here are at all widely documented. While examples of bipartite comitatives have been shown here to occur in a number of North/West African languages, they have rarely been explicitly identified as such. They have therefore been invisible to the typological work discussed in the introduction. However, an unambiguous but optional case, an example of which Stassen (2003:789) actually quotes without comment, is found in Acooli (Eastern Sudanic, Uganda):

When a personal pronoun has to be connected with another by the conjunction $k i$ 'and, together with', [g]enerally [f]or the first person [i.e. first noun phrase] (in the singular) the corresponding pronoun of the plural is used... Then the other person [noun phrase] [i]s added after the verb and connected with the preposition $k i$; the forementioned plural pronoun may be repeated after the verb in front of the preposition. [T] he same construction is often employed when nouns are connected. In this case the plural pronoun corresponding to the subject, i.e.: giïn, again precedes the preposition $k i$ followed by the noun. (Crazzolara 1938:66)

The requirement that the first pronoun be in the plural, agreeing with the combination rather than with the expected first term, exemplifies the cross-linguistically widespread phenomenon that Haspelmath (2004) terms "inclusory constructions".

This bipartite comitative is exemplified not only for pre-verbal subjects:

$\begin{array}{lllll}\text { Òkeelò } & \text { ò-cìttò } & \text { paàco gï̈n } & \text { ki làmïnnè } \\ \text { Okeelo } & 3 S g \text {-go } & \text { home they } & \text { with } & \text { his.sister }\end{array}$

'Okeelo went home with his sister.'

(Crazzolara 1938:66)

but also for direct objects:

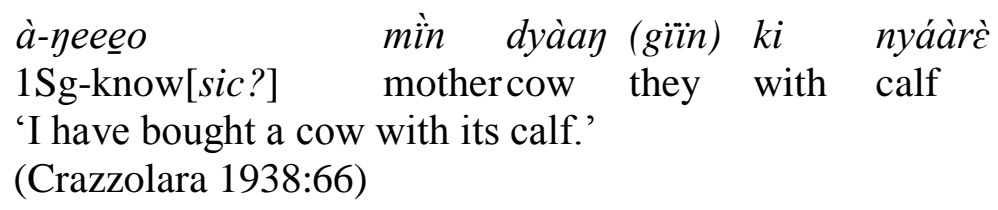

According to the widely accepted but unproven Nilo-Saharan hypothesis proposed by Greenberg (1963), Acooli and Songhay are very distantly related to one another. Even if this is accepted, however, it is unlikely that this feature is a shared retention, since the markers involved are not likely cognates, and the phenomenon is inconsistent among Acooli's nearest relatives; Dholuo (Kenya), which like Acooli belongs to the Lwoo subgroup of Western Nilotic, uses a presumably cognate preposition gi for 'with', but shows no sign of bipartite constructions (Tucker 1994:228). This suggests that the Acooli case, like the Songhay examples, represents an innovation within its immediate family resulting from some version of the cycle outlined. The scenario 
outlined above suggests that such an innovation should require Verb-Subject-Object order, and, in fact, Proto-West Nilotic has been reconstructed as having the basic order Verb-Subject-Object (Hieda 1991), in accordance with this prediction.

Comitative external agreement is also rather rare; it is absent from Corbett (2006), for example, and appears to have received no comprehensive treatment. A possible (partial) example is found in Bierebo, an Austronesian language of Vanuatu (Budd 2010), where the comitative migo, described as a "verbal preposition", takes a subject marking prefix indexing the combination of the accompanier and the accompanied. However, no evidence is given bearing on whether this marker belongs to a category of prepositions distinct from serial verbs, and Bierebo verbs in general display agreement with their subjects (although not usually, as here, with the combination). A parallel in the coordinative rather than comitative domain is reported for Walman, a language of Papua New Guinea, where coordinatives are commonly expressed by a transitive verb taking both subject and object agreement (Brown \& Dryer 2008).

\section{Conclusions}

The situation observed in Kwarandzyey exemplifies a previously unreported grammaticalisation chain whereby sentential afterthoughts consisting of pronoun-initial noun conjunctions can be pressed into service for expressing comitative relations and eventually turn into comitative adpositions marked with external argument marking agreement affixes. Several Songhay and Berber languages exhibit the early stages of this development. Table 8 represents the process:

\section{Table 8: How “and" develops into "AGR-with"}

\section{Form Meaning}

Stage 1: $\quad \mathrm{X}($ subject NP)..., $\underline{\text { Prox } \text { and } \mathrm{Y}}$ reanalysis (VS) / afterthought, self-correction

Stage 2: $\quad \mathrm{X}\left(\mathrm{NP}\right.$, any role)... $\underline{\text { Pro }_{\mathrm{x}} \text { and } \mathrm{Y}}$ bipartite comitative

Stage $3 \quad \mathrm{X} . . . \underline{\text { Agr }_{\mathrm{x}}-\text { with } \mathrm{Y}}$ comitative with external agreement

This grammaticalisation chain has the effect of reversing another well-attested one, the development COMITATIVE > NP-AND (Heine \& Kuteva 2002:80). The existence of both chains implies that some caution is needed in determining which sense of a polysemous 'and/with' form is original.

Both Stage 2 and Stage 3 appear cross-linguistically unusual, and are missing from previous typologies of conjunction. The demonstration that they exist, and are diachronically related to one another, thus extends our understanding of the conceptual space of morphosyntactic features, as well as of grammatical change. The bipartite comitative also helps explain cases that would otherwise appear to violate the Coordinate Structure Constraint.

\section{References}

Amaniss, Ali. 1980. Dictionnaire tamazight-français (parlers du Maroc centrale) [Tamazight-French dictionary (Central Moroccan dialects). http://www.amazighworld.org/uploadedfiles/dictionnaire_Francais_Tamazight.pdf (accessed 27 September, 2009).

Arkhipov, Alexandre. 2009. Comitative as a cross-linguistically valid category. In Patience Epps \& Alexandre Arkhipov (eds.), New challenges in typology: Transcending the borders and refining the distinctions, 223-246. (Trends in Linguistics Studies and Monographs 217). Berlin: Mouton de Gruyter.

Bellil, Rachid. 2006. Textes zénètes du Gourara [Zenati texts from Gourara]. Algiers: Centre National de Recherches Préhistoriques, Anthropologiques et Historiques.

Boukous, Ahmed. 1977. Langage et culture populaires au Maroc: essai de sociolinguistique [Popular speech and 
culture in Morocco: A sociolinguistic study]. Rabat: Dar El Kitab.

Brown, Lea \& Matthew S. Dryer. 2008. The verbs for "and" in Walman, a Torricelli language of Papua New Guinea. Language 84. 528-565.

Budd, Peter S. 2010. Topics in the grammar of Bierebo, Central Vanuatu, with a focus on the Realis/Irrealis categories. London: School of Oriental and African Studies doctoral thesis.

Cancel, Lt. 1908. Etude sur le dialecte de Tabelbala [Study of the dialect of Tabelbala]. Revue Africaine 270-271. 302347.

Christiansen-Bolli, Regula. 2010. A Grammar of Tadaksahak: A Berberised Songhay Language (Mali). Köln: Rüdiger Köppe.

Corbett, Greville G. 2006. Agreement. Cambridge: Cambridge University Press.

Crazzolara, J. Pasquale. 1938. A study of the Acooli language: grammar and vocabulary. London: Oxford University Press, for the International Institute of African Languages \& Cultures.

Destaing, Edmond. 1914. Dictionnaire francais-berbère: Dialecte des Beni-Snous [French-Berber dictionary: BeniSnous dialect]. (Publications de la Faculté des Lettres d'Alger 49). Paris: Ernest Leroux.

Ducroz, Jean-Marie \& Marie-Claire Charles. 1978. Lexique soney (Songay)-français: parler kaado du Gorouol [Soney (Songay)-French lexicon: Kaado dialect of Gorwol]. Paris: L'Harmattan.

Gelderen, Elly van. 2011. The linguistic cycle: Language change and the language faculty. New York: Oxford University Press.

Greenberg, Joseph H. 1963. The languages of Africa. Bloomington: Indiana University.

Hagège, Claude. 2010. Adpositions. Oxford: Oxford University Press.

Haspelmath, Martin. 2004. Coordinating constructions: An overview. In Martin Haspelmath (ed.), Coordinating constructions (Typological Studies in Language 58), 3-40. Amsterdam: John Benjamins.

Haspelmath, Martin. 2007. Coordination. In Timothy Shopen (ed.), Language typology and syntactic description, vol. II: Complex constructions, 1-51. Cambridge: Cambridge University Press.

Heath, Jeffrey (ed.). 1998. Texts in Koyra Chiini: Songhay of Timbuktu, Mali. (Wortkunst und Dokumentartexte in afrikanischen Sprachen 5). Köln: Rüdiger Köppe.

Heath, Jeffrey. 1999a. A grammar of Koyraboro (Koroboro) Senni: The Songhay of Gao, Mali. (Westfrikanische Studien 19). Köln: Rüdiger Köppe.

Heath, Jeffrey. 1999b. A grammar of Koyra Chiini: The Songhay of Timbuktu. (Mouton Grammar Library 19). Berlin: Mouton de Gruyter.

Heath, Jeffrey. 2005. Tondi Songway Kiini (Songhay, Mali): Reference grammar and TSK-English-French dictionary. (Stanford Monographs in African Languages). Stanford: CSLI.

Heath, Jeffrey. 2007. Humburi Senni grammar. http://www-personal.umich.edu/ jheath/Hombori_Grammar_entire.pdf (accessed 1 June, 2009).

Heine, Bernd \& Tania Kuteva. 2002. World lexicon of grammaticalization. Cambridge: Cambridge University Press.

Hieda, Osamu. 1991. Word order and word order change in western Nilotic. In Franz Rottland and Lucia Ndong'a Omondi (eds.), Proceedings of the 3rd Nilo-Saharan linguistics colloquium, Kisumu, Kenya, August 4-9, 1986 (Nilo-Saharan Linguistic Analyses and Documentation 6), 105-121. Köln: Rüdiger Köppe Verlag.

Kurath, Hans (ed.). 2001. Middle English dictionary. Ann Arbor: University of Michigan Press. http://quod.lib.umich.edu/m/med/ (accessed 21 June, 2012).

Lehmann, Christian \& Yong-Min Shin. 2005. The functional domain of concomitance. In Christian Lehmann (ed.), Typological studies in participation. (Studia Typologica 6), 9-102. Berlin: Akademie.

Mitchell, Terence F. 2009. Zuaran Berber (Libya): Grammar and texts. (Ed.) Harry Stroomer \& Stanly Oomen. (Berber Studies v. 26). Köln: Rüdiger Köppe.

Neises, Jackson \& Noelle Smith. 1995. Technical language manual for AFSI/NRM volunteers: Zarma. http://www.eric.ed.gov/ERICWebPortal/contentdelivery/servlet/ERICServlet?accno=ED402777 (accessed 21 June, 2012).

Nicolas, Francis. 1953. La langue berbère de Mauritanie [The Berber language of Mauritania]. (Mémoires de l'Institut Français d'Afrique Noire 33). Dakar: Institut Français d'Afrique Noire.

Palancar, Enrique. 2012. A typology of split conjunction. Linguistic Typology 16:2. 265-320.

Penchoen, Thomas G. 1973. Étude syntaxique d'un parler berbère (Ait Fraḥ de l'Aurès) [Syntactic Study of a Berber Dialect (Ait Frah of the Aurès)]. (Studi Magrebini 5). Napoli: Centro di Studi Magrebini.

Ross, John Robert. 1986. Infinite syntax! (Language and Being). Norwood, N.J: Ablex.

Rueck, Michael J. \& Niels Christiansen. 1999. Northern Songhay languages in Mali and Niger. SIL Electronic Survey Reports 008. http://www.sil.org/silesr/1999/008/nsonghay.pdf (accessed 1 June, 2009).

Sibomana, Leo. 2008. Le Zarma parlé: esquisse grammaticale, lexique, textes [Spoken Zarma: Grammar sketch, lexicon, texts]. Berlin: Lit.

Souag, Lameen. 2010a. Grammatical contact in the Sahara: Arabic, Berber, and Songhay in Tabelbala and Siwa. 
London: School of Oriental and African Studies doctoral thesis.

Souag, Lameen. 2010b. The Western Berber stratum in Kwarandzyey (Tabelbala, Algeria). In Dymitr Ibriszimow, Maarten Kossmann, Harry Stroomer \& Rainer Vossen (eds.), Études berbères V - Essais sur des variations dialectales et autres articles [Berber Studies V - Essays on dialectal variation and other articles], 177-189. Köln: Rüdiger Köppe.

Souag, Lameen. 2012. The subclassification of Songhay and its historical implications. Journal of African Languages and Linguistics 33(2). 181-213.

Stassen, Leon. 2003. Noun phrase conjunction: The coordinative and the comitative strategy. In Franz Plank (ed.), Noun phrase structure in the languages of Europe, 761-820. Berlin; New York: Mouton de Gruyter.

Stassen, Leon. 2011. Noun phrase conjunction. In Matthew S. Dryer \& Martin Haspelmath (eds.), The World Atlas of Language Structures Online. Max Planck Digital Library. http://wals.info/chapter/63 (accessed 20 June, 2012).

Stolz, Thomas, Cornelia Stroh \& Aina Urdze. 2006. On comitatives and related categories: A typological study with special focus on the languages of Europe. Berlin; New York: Mouton de Gruyter.

Stolz, Thomas, Cornelia Stroh \& Aina Urdze. 2011. Comitatives and instrumentals. In Matthew S. Dryer \& Martin Haspelmath (eds.), The World Atlas of Language Structures Online. Max Planck Digital Library. http://wals.info/chapter/52 (accessed 20 June, 2012).

Tucker, A. N. 1994. A grammar of Kenya Luo (Dholuo). (Nilo-Saharan Linguistic Analyses and Documentation 8). Köln: Köppe. 